Int. J. Electrochem. Sci., 15 (2020) 899 - 914

\title{
A Novel Borate Ion Selective Electrode Based On Carbon Nanotube-Silver Borate
}

\author{
Duygu Uner Bahar ${ }^{1}$, Cihan Topcu ${ }^{2}$, Didem Ozcimen ${ }^{1}$ and Ibrahim Isildak ${ }^{1, *}$ \\ ${ }^{1}$ Department of Bioengineering, Faculty of Chemical and Metallurgical Engineering, Yildiz Technical \\ University, Istanbul, Turkey \\ ${ }^{2}$ Department of Chemistry, Faculty of Arts and Sciences, Erzincan Binali Yildirim University, \\ Erzincan, Turkey \\ *E-mail: isildak@yildiz.edu.tr
}

doi: $10.20964 / 2020.01 .40$

Received: 1 June 2019 / Accepted: 7 July 2019 / Published: 30 November 2019

\begin{abstract}
A novel miniaturized borate selective composite membrane electrode based on carbon nanotube-silver borate is described. The developed electrode exhibited a stable and linear potentiometric behavior over the concentration range of $1 \times 10^{-1} \mathrm{M}$ and $1 \times 10^{-4} \mathrm{M}$ borate ion with a Nernstian slope of $34 \mathrm{mV} / \mathrm{decade}$ and a limit of detection of $2 \times 10^{-5} \mathrm{M}$. The electrode showed a clear selectivity to borate ion over sulfate, chloride, nitrate and many other inorganic acid anions. The response time of the electrode was found less than $14 \mathrm{~s}$. Potentiometric readings of the electrode were consistent, when $\mathrm{pH}$ was between 4 and 8 , through almost 3 months. The developed borate-selective composite membrane electrode was directly applied for the quantification of borate ions in real water samples. The results obtained by the developed electrode method was statistically analyzed and compared with those obtained by ICP-MS method. No significant differences for either accuracy or precision were observed.
\end{abstract}

Keywords: Borate selective composite membrane electrode, Borate in environmental waters, Potentiometry, Carbon nanotube-silver borate

\section{$\underline{\text { FULL TEXT }}$}

(C) 2020 The Authors. Published by ESG (www.electrochemsci.org). This article is an open access article distributed under the terms and conditions of the Creative Commons Attribution license (http://creativecommons.org/licenses/by/4.0/). 